\title{
Circulating $\mathrm{CD}^{+}$memory $\mathrm{T}$ cells give rise to a ${\mathrm{CD} 69^{+}}^{+}$resident memory $\mathrm{T}$ cell population in non-inflamed human skin.
}

Maria M. Klicznik ${ }^{1}$, Ariane Benedetti ${ }^{1}$ Angelika Stoecklinger ${ }^{1}$, Daniel J. Campbell ${ }^{2,3}$, Iris K. Gratz ${ }^{1,2,4}$

${ }^{1}$ Department of Biosciences, University of Salzburg, Salzburg, Austria

${ }^{2}$ Benaroya Research Institute, 1201 9th AVE, Seattle, WA 98101 USA

${ }^{3}$ Department of Immunology, University of Washington School of Medicine, Seattle WA 98109, USA.

${ }^{4}$ Division of Molecular Dermatology and EB House Austria, Department of Dermatology, Paracelsus Medical University Salzburg, Austria

Corresponding author: iris.gratz@sbg.ac.at
Abbreviations: $\mathrm{T}_{\mathrm{RM}}$, tissue resident memory $\mathrm{T}$ cells; PBMC, peripheral blood mononuclear cells; NSG, NOD-scid IL2r $\gamma^{\text {null }}$ mice; ES, engineered human skin; huPBMC-ES-NSG, NSG mice with grafted human PBMC and ES 


\begin{abstract}
The blood of human adults contains a pool of circulating $\mathrm{CD}^{+}$memory $\mathrm{T}$ cells and normal human skin contains a $\mathrm{CD} 4^{+} \mathrm{CD} 69^{+}$memory $\mathrm{T}$ cell population that produce IL17 in response to Candida albicans. Here we studied the generation of $\mathrm{CD} 4^{+} \mathrm{CD} 69^{+}$memory $\mathrm{T}$ cells in human skin from a pool of circulating $\mathrm{CD} 4^{+}$memory $\mathrm{T}$ cells.

Using adoptive transfer of human PBMC into a skin-humanized mouse model we discovered the generation of $\mathrm{CD} 4^{+} \mathrm{CD} 69^{+}$resident memory $\mathrm{T}$ cells in human skin in absence of infection or inflammation. These $\mathrm{CD} 4^{+} \mathrm{CD} 69^{+}$resident memory $\mathrm{T}$ cells were activated and displayed heightened effector function in response to Candida albicans. These studies demonstrate that a $\mathrm{CD} 4^{+} \mathrm{CD} 9^{+} \mathrm{T}$ cell population can be established in human skin from a pool of circulating $\mathrm{CD}^{+}$memory $\mathrm{T}$ cells in absence of infection/inflammation. The described process might be a novel way to spread antigen-specific immunity at large barrier sites even in absence of infection or inflammation.
\end{abstract}


Healthy human skin is protected by at least four phenotypically and functionally distinct subsets of memory $\mathrm{T}$ cells that are either recirculating or tissue-resident (Watanabe et al. 2015). Tissue resident memory $\mathrm{T}$ cells $\left(\mathrm{T}_{\mathrm{RM}}\right)$ are maintained within the tissue and show superior effector function over circulating memory $\mathrm{T}$ cells. $\mathrm{T}_{\mathrm{RM}}$ are defined by the expression of CD69 and/or CD103, both of which contribute to tissue retention (Mackay et al. 2015; Mackay et al. 2013). $\mathrm{CD}^{+} \mathrm{CD}^{+} 9^{+} \mathrm{T}_{\mathrm{RM}}$ are generated in response to microbes such as C.albicans and provide protective immunity upon secondary infection in mouse skin, and a similar $\mathrm{CD} 4^{+} \mathrm{CD} 69^{+} \mathrm{T}$ cell population that produced IL17 in response to heat killed C.albicans ex vivo was found in human skin (Park et al. 2018). By contrast, a population of fast migrating $\mathrm{CD}^{-} 9^{-} \mathrm{CD} 4^{+}$memory $\mathrm{T}$ cells entered murine dermis even 45 days after C.albcians infection when the infection was already resolved, hence they were likely not recruited in response to antigen. These data suggest that in absence of infection/inflammation, $\mathrm{T}$ cell memory in human skin is heterogenous and composed of resident and migratory memory $\mathrm{T}$ cell populations. In mouse parabiosis experiments $\mathrm{CD} 4^{+}$memory $\mathrm{T}$ cells were able to modulate CD69 and/or CD103 expression, exit the skin and were found in equilibrium with the circulation. However, it is unclear if these cells could re-migrate to the skin and re-express CD69 upon entry into the tissue (Collins et al. 2016). Re-entry into the tissue to regain residency at distant skin sites would facilitate dispersion of protective immunity across large barrier organs such as the skin. The presence of a migratory memory $\mathrm{T}$ cell population in previously infected skin (Park et al. 2018) implies the existence of circulating memory T cells that can enter non-infected skin in steady state. So far it remains to be elucidated if human circulating $\mathrm{CD}^{+}{ }^{+}$memory $\mathrm{T}$ cells can give rise to resident memory $\mathrm{T}$ cells in human skin in absence of acute infection.

We therefore set out to test whether human peripheral blood mononuclear cells (PBMC) contain a circulating population of memory $\mathrm{CD}^{+} \mathrm{T}$ cells with the potential to enter noninflamed/non-infected skin sites distinct from the site of initial antigen-encounter, and assume 
the phenotype and function of $\mathrm{CD} 69^{+} \mathrm{CD} 4^{+}$resident memory $\mathrm{T}$ cells upon tissue entry. For this, we utilized a novel xenografting mouse model (detailed in Klicznik et al. linked submission) in which we adoptively transferred human PBMC into immunodeficient NODscid IL2ry ${ }^{\text {null }}$ (NSG) mice (King et al. 2008) mice that carried engineered human skin (ES), which was devoid of any resident leukocytes. Within this model, designated huPBMC-ESNSG, we found that transferred PBMC preferentially infiltrated the human but not murine skin, and that the human skin tissue promotes $\mathrm{T}$ cell maintenance and function in absence of inflammation or infection (Klicznik et al. linked submission). In line with previous reports (Clark et al. 2006), we found that human PBMC contained a proportion of skin homing $\mathrm{CLA}^{+} \mathrm{CD} 45 \mathrm{~A}^{-} \mathrm{CD} 4^{+}$memory $\mathrm{T}$ cells and, upon adoptive transfer skin-tropic $\mathrm{CLA}^{+} \mathrm{CD} 4^{+} \mathrm{T}$ cells were significantly enriched in the ES compared to the spleen (Fig. 1a). Interestingly among these CLA ${ }^{+}$cells, the majority expressed the $\mathrm{T}_{\mathrm{RM}}$ marker CD69 in the ES (Fig.1b). Importantly, the increased proportion of $\mathrm{CD}^{+} \mathrm{T}$ cells expressing CD69 in the ES was likely not due to tissue-derived inflammatory cues (Mackay et al. 2012) such as IL1 $\alpha$, IL1 $\beta$, IL18, IL23, IFN $\gamma$, TNF $\alpha$ and TNF $\beta$, which were found at equal or lower levels as in healthy human skin (Supplement Fig.1). Nor was CD69 expression due to local activation of T cells by antigen-presenting cells (APC), which are virtually absent in the ES of this PBMC-ES-NSG model (Klicznik et al., linked submission). Some of the $\mathrm{CD}^{+} 9^{+}$cells in the ES expressed CD103, a marker of human $\mathrm{CD}^{+} \mathrm{CLA}^{+} \mathrm{T}_{\mathrm{RM}}$ (Klicznik et al. 2018) (Fig. 1c). Additionally, $\mathrm{CD}^{-}$but not $\mathrm{CD}^{-} 9^{+}$cells within the ES and the spleen expressed CD62L, a marker of circulating memory T cells (Watanabe et al. 2015) (Fig. 1d). These two distinct memory subsets, a resident memory-like $\mathrm{CD} 4^{+} \mathrm{CD} 69^{+}$and a $\mathrm{CD} 69^{-} \mathrm{CD} 62 \mathrm{~L}^{+}$migratory population, replicate two major sets of memory T cells in healthy human skin (Park et al. 2018). Taken together, these data show that circulating $\mathrm{CD}^{+}$memory $\mathrm{T}$ cells have the ability to up-regulate markers of tissue-residency upon entry into non-inflamed/non-infected human skin. 
$\mathrm{CD} 9^{+} \mathrm{T}_{\mathrm{RM}}$ represent a transcriptionally, phenotypically, and functionally distinct $\mathrm{T}$ cell subset at multiple barrier sites with enhanced capacity for the production of effector cytokines compared to circulating cells (Kumar et al. 2017). A proportion of skin-tropic human CD4 ${ }^{+} \mathrm{T}$ cells is specific for C.albicans (Acosta-Rodriguez et al. 2007), and to compare the function of $\mathrm{CD} 9^{+}$and $\mathrm{CD} 69^{-} \mathrm{CD}^{+} \mathrm{T}$ cells infiltrating the ES, we injected the ES after adoptive transfer of human PBMC with autologous monocyte derived DC that were pulsed with heat killed C.albicans. (Fig. 2a). Upon antigen-challenge CD69+ memory T cells produced higher levels of effector cytokines such as IL17, IFN $\gamma$, TNF $\alpha$ and IL2 (Fig. 2b-e), which is in line with a rapid memory response upon secondary infections.

Here we show for the first time that circulating human memory $\mathrm{CD}^{+} \mathrm{T}$ cells can enter skin in the absence of infection or inflammation and give rise to a $\mathrm{CD} 69^{+} \mathrm{CD} 4^{+}$memory $\mathrm{T}$ cell population (Fig.1b). Importantly these recently immigrated resident memory T cells produce substantially higher levels of effector cytokines (Fig.2b-e) in response to C.albicans, indicating that they represent the main responding memory population, which is in line with recent findings in murine skin (Park et al. 2018). It remains to be elucidated whether $\mathrm{CD} 9^{+} \mathrm{CD} 4^{+}$memory $\mathrm{T}$ cells reside within the ES long-term or if they can modulate CD69 expression and leave the tissue again. The ability of circulating $\mathrm{CD} 4^{+}$memory $\mathrm{T}$ cells to enter non-inflamed skin sites, where they assume the phenotypical and functional profile of resident memory $\mathrm{T}$ cells reveals a novel mechanism to generate and disperse protective memory in large barrier organs, such as the skin.

\section{Conflict of Interest}

The authors declare no conflict of interest.

\section{Acknowledgements:}

We thank all human subjects for blood and skin donation. We thank Dr. Stefan Hainzl, EB House Austria, Department of Dermatology, University Hospital of the Paracelsus Medical 
University Salzburg, Austria, for the immortalization of primary human keratinocytes and fibroblasts. This work was supported by the Focus Program "ACBN" of the University of Salzburg, Austria, and NIH grant R01AI127726 awarded to IKG and DJC. MMK is part of the PhD program Immunity in Cancer and Allergy, funded by the Austrian Science Fund (FWF, grant W 1213) and was recipient of a DOC Fellowship of the Austrian Academy of Sciences.

\section{Author Contributions:}

IGK, DJC and MMK conceptualized the study, MMK designed and performed the experiments, MMK and $\mathrm{AB}$ acquired the data, GS acquired human samples, MMK performed data analysis, MMK and IGK interpreted data and wrote the manuscript. All authors reviewed the final version of the manuscript.

\section{References}

Acosta-Rodriguez EV, Rivino L, Geginat J, Jarrossay D, Gattorno M, Lanzavecchia A, et al. Surface phenotype and antigenic specificity of human interleukin 17-producing $\mathrm{T}$ helper memory cells. Nat. Immunol. 2007;8(6):639-46

Clark RA, Chong B, Mirchandani N, Brinster NK, Yamanaka K-I, Dowgiert RK, et al. The vast majority of CLA+ T cells are resident in normal skin. J. Immunol. Baltim. Md 1950. 2006;176(7):4431-9

Collins N, Jiang X, Zaid A, Macleod BL, Li J, Park CO, et al. Skin CD4 ${ }^{+}$memory T cells exhibit combined cluster-mediated retention and equilibration with the circulation. Nat. Commun. 2016;7:11514 
King M, Pearson T, Shultz LD, Leif J, Bottino R, Trucco M, et al. A new Hu-PBL model for the study of human islet alloreactivity based on NOD-scid mice bearing a targeted mutation in the IL-2 receptor gamma chain gene. Clin. Immunol. Orlando Fla. 2008;126(3):303-14

Klicznik MM, Morawski PA, Höllbacher B, Varkhande S, Motley S, Rosenblum MD, et al. Exit of human cutaneous resident memory CD4 T cells that enter the circulation and seed distant skin sites. bioRxiv. 2018;361758

Kumar BV, Ma W, Miron M, Granot T, Guyer RS, Carpenter DJ, et al. Human TissueResident Memory T Cells Are Defined by Core Transcriptional and Functional Signatures in Lymphoid and Mucosal Sites. Cell Rep. 2017;20(12):2921-34

Mackay LK, Braun A, Macleod BL, Collins N, Tebartz C, Bedoui S, et al. Cutting Edge: CD69 Interference with Sphingosine-1-Phosphate Receptor Function Regulates Peripheral T Cell Retention. J. Immunol. 2015;194(5):2059-63

Mackay LK, Rahimpour A, Ma JZ, Collins N, Stock AT, Hafon M-L, et al. The developmental pathway for $\mathrm{CD} 103^{+} \mathrm{CD}^{+}$tissue-resident memory T cells of skin. Nat. Immunol. 2013;14(12):1294-301

Mackay LK, Stock AT, Ma JZ, Jones CM, Kent SJ, Mueller SN, et al. Long-lived epithelial immunity by tissue-resident memory T (TRM) cells in the absence of persisting local antigen presentation. Proc. Natl. Acad. Sci. U. S. A. 2012;109(18):7037-42

Park CO, Fu X, Jiang X, Pan Y, Teague JE, Collins N, et al. Staged development of longlived T-cell receptor $\alpha \beta$ TH17 resident memory T-cell population to Candida albicans after skin infection. J. Allergy Clin. Immunol. 2018;142(2):647-62 
bioRxiv preprint doi: https://doi.org/10.1101/490094; this version posted December 9, 2018. The copyright holder for this preprint (which was not certified by peer review) is the author/funder, who has granted bioRxiv a license to display the preprint in perpetuity. It is made available under aCC-BY-NC-ND 4.0 International license.

Watanabe R, Gehad A, Yang C, Campbell L, Teague JE, Schlapbach C, et al. Human skin is protected by four functionally and phenotypically discrete populations of resident and recirculating memory T cells. Sci. Transl. Med. 2015;7(279):279ra39 


\section{Figure legends:}

Figure 1: $\mathrm{CD}^{+}$memory $\mathrm{T}$ cells derived from the circulation up-regulate markers of residency and skin-tropism in engineered human skin. Engineered skin (ES) was generated on immunodeficient NSG mice. After complete wound healing ( $>30$ days) $3 \times 10^{6}$ autologous human PBMC were adoptively transferred. Single cell suspensions of spleen and ES of huPBMC-ES-NSG were prepared 21 days after adoptive transfer and analyzed by flow cytometry together with ingoing PBMC (a-b) Representative flow cytometry analysis and graphical summary of expression of indicated markers by $\mathrm{CLA}^{+} \mathrm{CD} 45 \mathrm{RA}-\mathrm{CD} 4{ }^{+} \mathrm{CD}^{+}$live leukocytes. Mean +/- SD, statistical significance determined by paired t-test; (c-d) Representative flow cytometry analysis and graphical summary of the expression of indicated markers by CD69+ or CD69- cells in ES and spleen (S) gated on $\mathrm{CLA}^{+} \mathrm{CD} 45 \mathrm{RA}-\mathrm{CD} 4{ }^{+} \mathrm{CD}^{+}$live leukocytes. Mean +/- SD; one-way RM ANOVA with Dunett's test for multiple comparison to CD69+ cells in ES.

\section{Figure 2: CD69+CD4+ cutaneous memory $T$ cells show a distinct cytokine and} activation profile in response to C.albicans. ES of huPBMC-ES-NSG mice was intradermally injected with heat killed C.albicans loaded onto autologous moDCs. Single cell suspensions of the ES were prepared and analyzed for intracellular cytokine secretion upon PMA/ionomycin stimulation (a) Experimental set-up; (b-e) Graphical summary of the proportion of positive cells of the indicated markers among CD69+ or CD69- cells gated on $\mathrm{CLA}^{+} \mathrm{CD} 45 \mathrm{RA}-\mathrm{CD} 4{ }^{+} \mathrm{CD}^{+}$live leukocytes. Mean +/- SD; statistical significance determined by paired Student's t-test

Supplementary Figure 1: Analysis of pro-inflammatory cytokine levels in ES of huPBMC-ES-NSG mice in comparison to healthy human skin. ES and skin were 
bioRxiv preprint doi: https://doi.org/10.1101/490094; this version posted December 9, 2018. The copyright holder for this preprint (which

was not certified by peer review) is the author/funder, who has granted bioRxiv a license to display the preprint in perpetuity. It is made available under aCC-BY-NC-ND 4.0 International license.

weighed and analyzed for indicated cytokine levels using a bead-based multicomponent assay. Graphical summary shows concentration of indicated cytokine per mg skin;

Mean +/- SD; statistical significance determined by paired Student's t-test 
a
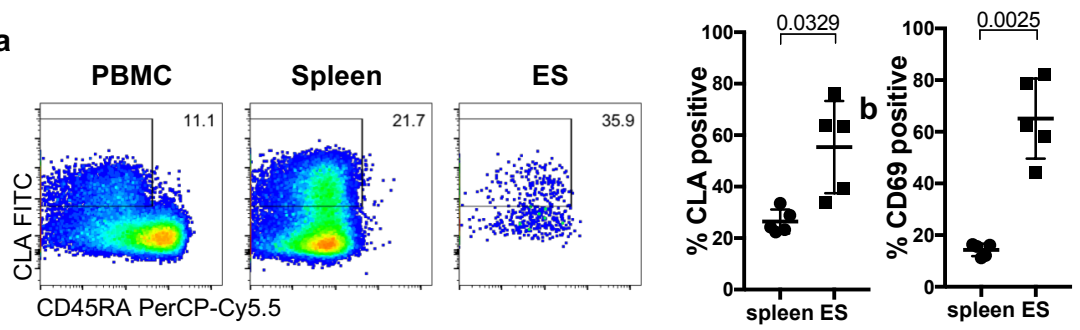

c
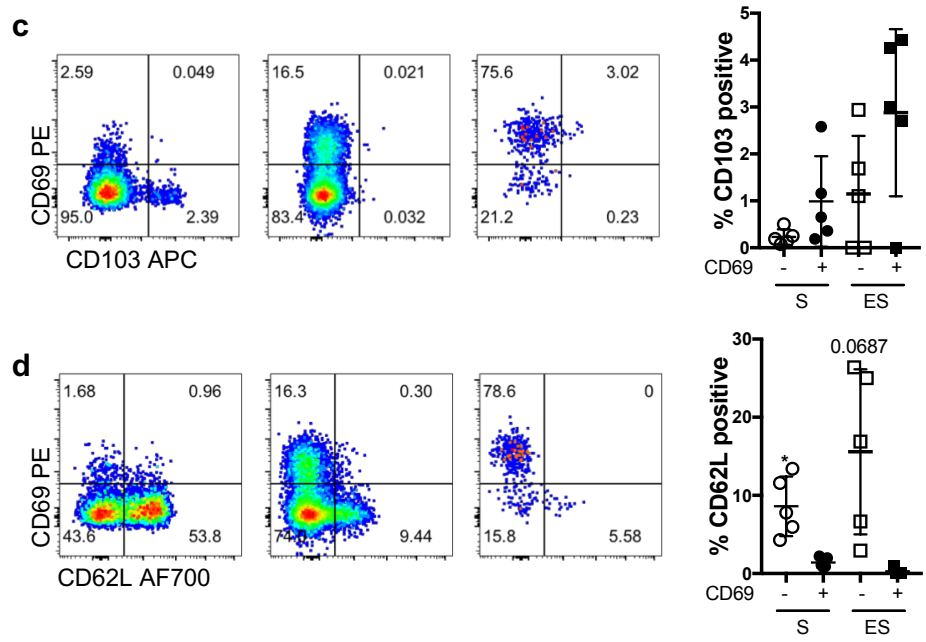

Figure 1: $\mathrm{CD}^{+}$memory $\mathrm{T}$ cells derived from the circulation upregulate markers of residency and skin-tropism in engineered human skin. 

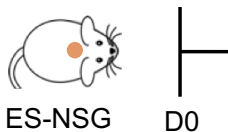

Stimulation of ES single cell suspensions with PMA/ionomycin and flow

ES-NSG

D0 cytometry analysis
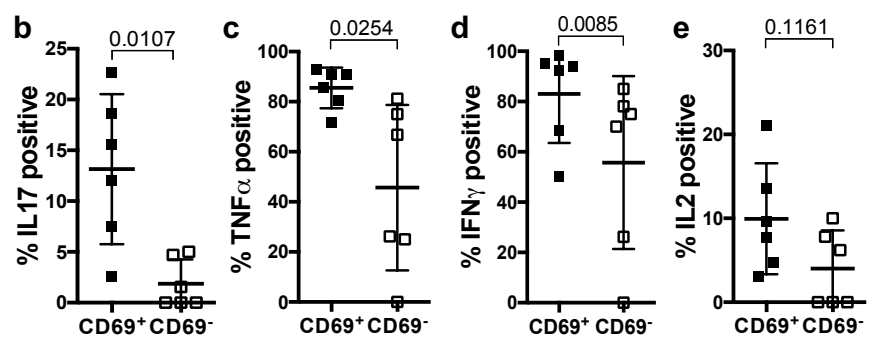

Figure 2: $\mathrm{CD} 69^{+} \mathrm{CD} 4^{+}$memory $\mathrm{T}$ cells show a distinct cytokine and activation profile in response to C.albicans. 

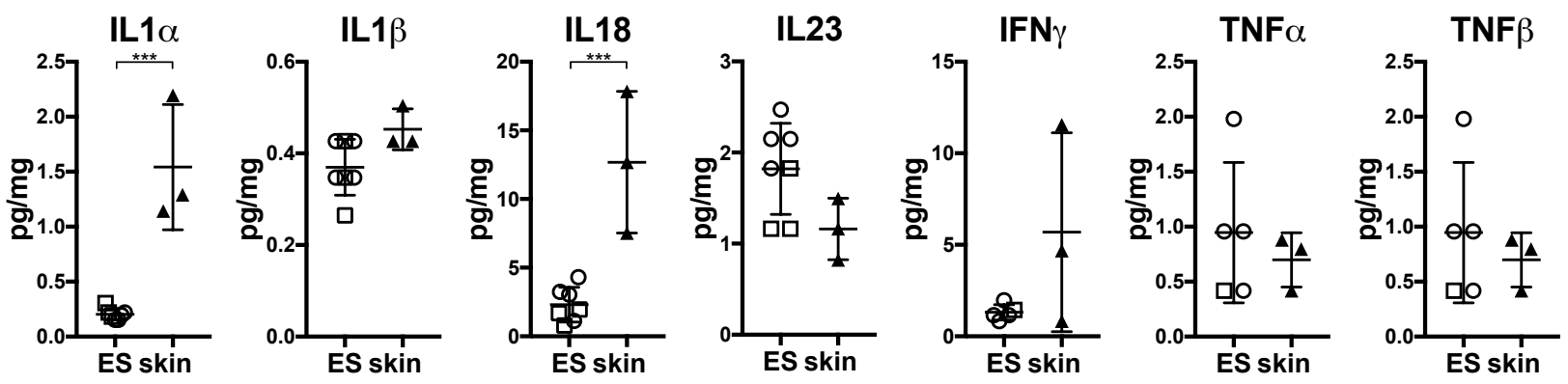

Supp. Figure 1: Inflammatory cytokines are secreted at lower or equal levels in ES compared to healthy human skin 


\section{Material and Methods}

Mice. Animal studies were approved by the Austrian Federal Ministry of Science, Research and Economy. NOD.Cg-Prkdcscid Il2rgtm $1 \mathrm{Wj1} / \mathrm{SzJ}$ (NSG) mice were obtained from The Jackson Laboratory and bred and maintained in a specific pathogen-free facility in accordance with the guidelines of the Central Animal Facility of the University of Salzburg.

Human specimens. Normal human skin was obtained from patients undergoing elective surgery, in which skin was discarded as a routine procedure. Blood and/or discarded healthy skin was donated upon written informed consent at the University Hospital Salzburg, Austria.

\section{PBMC isolation for adoptive transfer into NSG recipients and flow cytometry.}

Human PBMC were isolated from full blood using Ficoll-Hypaque (GE-Healthcare; GE171440-02) gradient separation. PBMC were frozen in FBS with 10\% DMSO (Sigma-Aldrich; D2650), and before adoptive transfer thawed and rested overnight at $37^{\circ} \mathrm{C}$ and $5 \% \mathrm{CO}_{2}$ in RPMIc (RPMI 1640 (Gibco; 31870074) with 5\% human serum (Sigma-Aldrich; H5667 or H4522), 1\% penicillin/streptomycin (Sigma-Aldrich; P0781), 1\% L-Glutamine (Gibco; A2916801), 1\% NEAA (Gibco; 11140035), 1\% Sodium-Pyruvate (Sigma-Aldrich; S8636) and $0.1 \% \beta$-Mercaptoethanol (Gibco; 31350-010). Cells were washed with PBS and $3 \times 10^{6}$ PBMC/mouse intravenously injected. Murine neutrophils were depleted with mLy6G (Gr-1) antibody (BioXcell; BE0075) as described before (Racki et al. 2010).

Generation of engineered skin (ES). Human keratinocytes and fibroblasts were isolated from human skin and immortalized using human papilloma viral oncogenes E6/E7 HPV as previously described (Merkley et al. 2009). Cells were cultured in Epilife (Gibco, MEPICF500) or DMEM (Gibco; 11960-044) containing 2\% L-Glutamine, 1\% Pen/Strep, 
$10 \%$ FBS, respectively. Per mouse, $1-2 \times 10^{6}$ keratinocytes were mixed 1:1 with autologous fibroblasts in 400 $\mu 1$ MEM (Gibco; 11380037) containing 1\% FBS, 1\% L-Glutamine and 1\% NEAA for in vivo generation of engineered skin as described (Wang et al. 2000).

T cell isolation from skin tissues for flow cytometry. Healthy human skin and ES were digested as previously described (Sanchez Rodriguez et al. 2014). Approximately $1 \mathrm{~cm}^{2}$ of skin was digested overnight in $5 \% \mathrm{CO}_{2}$ at $37^{\circ} \mathrm{C}$ with $3 \mathrm{ml}$ of digestion mix containing $0.8 \mathrm{mg} / \mathrm{ml}$ Collagenase Type 4 (Worthington; \#LS004186) and 0.02mg/ml DNase (SigmaAldrich; DN25) in RPMIc. ES were digested in 1ml of digestion mix. Samples were filtered, washed and stained for flow cytometry or stimulated for intracellular cytokine staining.

Flow cytometry. Cells were stained in PBS for surface markers. For detection of intracellular cytokine production, spleen and skin single cell suspensions and PBMC were stimulated with 50 ng/ml PMA (Sigma-Aldrich; P8139) and $1 \mu \mathrm{g} / \mathrm{ml}$ Ionomycin (Sigma-Aldrich; I06434) with $10 \mu \mathrm{g} / \mathrm{ml}$ Brefeldin A (Sigma-Aldrich; B6542) for $3.5 \mathrm{hrs}$. For permeabilization and fixation Foxp3 staining kit (Invitrogen; 00-5523-00) were used. Data were acquired on BD FACS Canto II (BD Biosciences) or Cytoflex LS (Beckman Coulter) flow cytometers and analyzed using FlowJo software (Tree Star, Inc.) A detailed list of the used antibodies can be found in the Supplements.

Statistical analysis. Statistical significance was calculated with Prism 7.0 software (GraphPad) by RM ANOVA with Dunett's multiple comparisons test, or by un-paired student's t-test as indicated. Error bars indicate mean ${ }^{+} /-$standard deviation. 
bioRxiv preprint doi: https://doi.org/10.1101/490094; this version posted December $9,2018$. The copyright holder for this preprint (which

was not certified by peer review) is the author/funder, who has granted bioRxiv a license to display the preprint in perpetuity. It is made available under aCC-BY-NC-ND 4.0 International license.

\section{References}

Merkley MA, Hildebrandt E, Podolsky RH, Arnouk H, Ferris DG, Dynan WS, et al. Largescale analysis of protein expression changes in human keratinocytes immortalized by human papilloma virus type 16 E6 and E7 oncogenes. Proteome Sci. 2009;7:29

Racki WJ, Covassin L, Brehm M, Pino S, Ignotz R, Dunn R, et al. NOD-scid IL2rgamma(null) mouse model of human skin transplantation and allograft rejection. Transplantation. 2010;89(5):527-36

Sanchez Rodriguez R, Pauli ML, Neuhaus IM, Yu SS, Arron ST, Harris HW, et al. Memory regulatory T cells reside in human skin. J. Clin. Invest. 2014;124(3):1027-36

Wang CK, Nelson CF, Brinkman AM, Miller AC, Hoeffler WK. Spontaneous cell sorting of fibroblasts and keratinocytes creates an organotypic human skin equivalent. J. Invest.

Dermatol. 2000;114(4):674-80 
bioRxiv preprint doi: https://doi.org/10.1101/490094; this version posted December 9,2018 . The copyright holder for this preprint (which was not certified by peer review) is the author/funder, who has granted bioRxiv a license to display the preprint in perpetuity. It is made available under aCC-BY-NC-ND 4.0 International license.

\section{Table S1: Detailed list of antibodies and reagents}

Tissue preparation

Reagent

DNAse

RPMI 1640

human serum

Penicillin/streptavidin

L-Glutamine

NEAA

Sodium-Pyruvat

$\beta$-Mercaptoethanol

PBS

Ficoll Paque Plus

$\begin{array}{ll}\text { Company } & \text { Catalog number } \\ \text { Worthington } & \text { LS004186 } \\ \text { Sigma-Aldrich } & \text { DN25 } \\ \text { Gibco } & 31870074 \\ \text { Sigma-Aldrich } & \text { H5667/H4522 } \\ \text { Sigma-Aldrich } & \text { P0781 } \\ \text { Gibco } & \text { A2916801 } \\ \text { Gibco } & 11140035 \\ \text { Sigma-Aldrich } & \text { S } 8636 \\ \text { Gibco } & 31350-010 \\ \text { Gibco } & 14190169 \\ \text { GE-Healthcare } & \text { GE17-1440-02 }\end{array}$

Cellular activation

\section{Reagent}

\section{Company}

Sigma-Aldrich

Invitrogen

\section{Catalog number}

Foxp3 / Transcription Factor Staining Buffer Set

lonomycin

PMA

Cytokine/Chemokine/Growth Factor 45-Plex Human ProcartaPlex ${ }^{\mathrm{TM}}$

Sigma-Aldrich

B6542

Sigma-Aldrich

00-5523-00

Invitrogen

P8139

Skin cell culture and transplantation

$\begin{array}{lll}\text { Reagent } & \text { Company } & \text { Catalog number } \\ \text { Epilife } & \text { Gibco } & \text { MEPICF500 } \\ \text { DMEM } & \text { Gibco } \\ \text { MEM } & \text { Gibco } \\ \text { TrypLE express } & \text { Gibco }\end{array}$

Tissue preparation from mice

Reagent

BD Pharm Lyse

\section{Antibodies}

\section{Reagent}

CLA FITC (HECA-452)

CD1a FITC (HI149)

CD3 BV421 (UCHT1)

CD3 bv605 (SK7)

CD4 PE-594 (RPA-T4)

CD4 PE-Cy5.5 (RPA-T4)

CD8 PE (OKT8)

CD14 bv421 (M5E2)

CD45 BV785 (HI30)

CD45RAPerCP-Cy5.5 (HI100)

CD62L AF700 (DREG-56)

CD69 PE (FN50)

CD69 PerCP/eFluor710 (FN50)

CD86 PE (B7-2)

CD103 APC (Ber-ACT8)

CCR7 bv605 (G043H7)

IFNg PE-Cy7 (B27)

IL-2 PE (MQ1-17H12)

IL17A APC (BL168)

TNFa FITC (Mab11)

Fixable Viability Dye eFluor ${ }^{\mathrm{TM}} 780$

mLy6G (Gr-1) InVivoMab RB6-8C5

\section{Company}

BD

\section{Company}

Biolegend

BioLegend

BioLegend

BioLegend

BioLegend

BioLegend

eBioscience

BioLegend

BioLegend

BioLegend

Biolegend

BioLegend

eBioscience

eBioscience

BioLegend

BioLegend

BioLegend

eBioscience

BioLegend

BioLegend

eBioscience

BioXcell
Catalog number

555899

\section{Catalog number}

321306

300104

300434

344835

300548

300510

12-0086-42

301830

304048

304122

304820

310906

46-0699-42

12-0869-41

350216

353224

506518

12-7029-42

512334

502915

65-0865-14

BE0075 